\title{
Penerapan Metode Forecast Exponential Smoothing pada Jumlah Pasien Puskesmas
}

\author{
Dwi Aprilia \\ Departemen Biostatistika dan Kependudukan \\ Fakultas Kesehatan Masyarakat Universitas Airlangga \\ Jl. Mulyorejo Kampus C Unair, Surabaya, 60115 \\ E-mail:april.bsn174@gmail.com
}

\begin{abstract}
Exponential smoothing was forecast method with reducing fluctuations of forecast results used data from the past. Increasing the number of patients had to was accompanied by facilities and tools supporting adequate services. The research purposed to predict the number of patient the health center Mulyorejo. The results showed that number of patient the health center Mulyorejo fluctuating every month. Results of forecast in 2016 increasing total patients there in April in the amount 3367 of patients. This also happened on general clinic with a number of patients amount 2643 of pastient. Increasing patient on poli gigi and poli KIA were on October and November amount 322 and 529 patients. MAPE value was produced the forecast total patient was 8,742, general clinic was 6,069, teeth poly was 12,579, and KIA poly was 23,139. Fluctuations in the number of patient visits the health center Mulyorejo more influenced by the number of patient visits in general clinic. Suggestions are expected for policy makers should be related planning tools, medicine, and health personnel needed in which the predicted number of visits will be increased in each poli in Puskesmas Mulyorejo.
\end{abstract}

Keywords: exponensial smoothing, forecasting, patient, public health center

\begin{abstract}
ABSTRAK
Exponensial smoothing merupakan metode forecast dengan cara mengurangi atau memuluskan fluktuasi dari hasil forecast dengan menggunakan data di masa lalu. Jumlah pasien yang semakin bertambah harus diiringi dengan fasilitas dan alat penunjang pelayanan yang memadai. Tujuan dari penelitian ini adalah untuk meramalkan jumlah kunjungan pasien Puskesmas Mulyorejo. Hasil penelitian menunjukkan jumlah kunjungan pasien Puskesmas Mulyorejo mengalami fluktuasi setiap bulan. Hasil forecast tahun 2016 kenaikan total kunjungan pasien terdapat pada bulan April yaitu sebesar 3367 pasien. Hal ini juga terjadi pada poli umum dengan jumlah pasien sebesar 2643 pasien. Kenaikan kunjungan pasien untuk poli gigi dan poli KIA adalah pada bulan Oktober dan November yaitu sebesar 322 dan 529 pasien. Nilai MAPE yang dihasilkan pada forecast total kunjungan adalah 8,742, poli umum 6,069, poli gigi 12,579, dan poli KIA 23,139. Fluktuasi jumlah kunjungan pasien Puskesmas Mulyorejo lebih dipengaruhi oleh jumlah kunjungan pasien di poli umum. Saran yang diharapkan bagi pengambil kebijakan sebaiknya dilakukan perencanaan terkait alat, obat, serta tenaga kesehatan yang dibutuhkan pada bulan dimana diramalkan jumlah kunjungan akan mengalami peningkatan di tiap poli di Puskesmas Mulyorejo.
\end{abstract}

Kata kunci: exponensial smoothing, forecast, pasien, puskesmas

\section{PENDAHULUAN}

Analisis deret berkala merupakan salah satu model/teknik dalam forecast yang banyak dilakukan dalam berbagai bidang, misal teknik, pertanian, kedokteran ekonomi, dan geofisik. Tujuan dari pemodelan deret berkala tersebut selain untuk forecast adalah untuk melakukan pengendalian dan mengenali pola perilaku suatu sistem. Ada beberapa model forecast dalam analisis deret berkala yaitu berdasarkan pada analisis hubungan antar variabel yang akan diramalkan dengan variabel waktu antara lain ARIMA Box-Jenkins, metode pemulusan, dan proyeksi tren (Wardani \& Pereira, 2010).

Model forecast penghalusan (exponential smoothing) merupakan salah satu model forecast data berkala (time series). Eksponensial smoothing merupakan metode forecast terhadap objek pengamatan terbaru. Metode forecast ini menitikberatkan penurunan prioritas pada data yang lebih lama, artinya metode ini lebih memperhatikan nilai observasi terbaru (Raharja dkk, 2010). 
Metode eksponensial smoothing adalah suatu prosedur dengan mengulang perhitungan secara terus menerus menggunakan data observasi terbaru. Setiap data yang digunakan pada metode ini diberi bobot yang disimbolkan alpha, di mana bobot ini ditentukan secara bebas dengan trial and eror. Nilai alpha berkisar antara 0 sampai dengan 1. Nilai alpha yang menghasilkan nilai tingkat kesalahan yang paling kecil akan dipilih untuk digunakan dalam model forecast (Garpersz, 2005).

Metode forecast exponensial smoothing ada beberapa macam yaitu single exponensial smoothing, double exponensial smoothing, dan tripel exponensial smoothing. Single exponensial smoothing merupakan metode forecast yang memberikan pembobotan secara exponensial pada data yang lebih lama, data yang lebih baru akan diberi bobot yang lebih besar. Metode ini digunakan untuk data yang berpola fluktuasi acak tanpa adanya unsur trend dan musiman (Hartono dkk, 2012). Metode double exopensial smoothing atau disebut juga metode dari Brown merupakan metode pemulusan dengan menggunakan dua kali pemulusan dan satu parameter. Metode ini digunakan untuk data yang membentuk pola trend. Metode triple exponensial smoothing merupakan metode merupakan metode dengan tiga parameter disebut juga metode Winter. Metode ini digunakan apabila pola data berbentuk trend dan ada unsur musiman (Tannady \& Andrew, 2013).

Metode penghalusan mempunyai banyak kelebihan bila dibandingkan dengan metode lain diantaranya adalah data-data dioperasikan dengan efisien, data yang dibutuhkan sedikit, dapat digunakan untuk mengolah data yang berisi trend tertentu atau pola musiman dengan cara memodifikasi, baik secara manual maupun dengan komputer biaya yang dibutuhkan murah. Metode eksponensial smoothing mempunyai track record keberhasilan yang baik (Yuniastari dan Wirawan, 2014).

Seiring bertambahnya jumlah populasi manusia dan semakin berkembangnya perekonomian maka kesadaran masyarakat akan kesehatan semakin meningkat pula. Hal ini dapat meningkatkan jumlah pengunjung di fasilitas kesehatan, salah satunya puskesmas. Jumlah pasien yang meningkat harus diiringi dengan kesiapan puskesmas terkait pemenuhan fasilitas dan peralatan penunjang fasilitas (Fuad \& Wahyuni, 2014).

Pelayanan fasilitas kesehatan kepada pasien merupakan kunci utama dalam memberikan kepuasan pasien. Kepuasan yang didapat dari pasien dapat dinilai dari segi tangibility, reliability, responsiveness, assurance, dan empaty (Sudian, 2011). Beberapa aspek tersebut dapat terlaksana dengan baik apabila ada perencanaan yang matang. Perencanaan yang perlu dilakukan untuk aspek-aspek tersebut adalah perencanaan terkait fasilitas pelayanan kesehatan, tenaga kerja, alat serta obat-obatan yang dibutuhkan untuk pelayanan. Permasalahan yang terjadi di Puskesmas Mulyorejo adalah jumlah pasien yang harus dilayani tidak sebanding dengan sumber daya yang ada di puskesmas tersebut. Ketersediaan sumber daya yang tidak memadai dapat mempengaruhi waktu penanganan pasien. Sumber daya yang ada di puskesmas tersebut harus bekerja di luar kapasitasnya (Farihul dkk, 2012).

Data kunjungan pasien di Puskesmas Mulyorejo didapatkan data selama 3 tahun terakhir yakni tahun 2013 jumlah kunjungan pasien sebesar 19.310 pasien, tahun 2014 sebesar 24.092, sedangkan tahun 2015 sebesar 34.001 pasien. Selama 3 tahun berturut-turut jumlah kunjungan pasien mengalami kenaikan. Kenaikan jumlah kunjungan pasien tersebut tidak diiringi dengan penambahan jumlah sumber daya yang profesional serta persediaan logistik lainnya. Hal ini berpengaruh terhadap pelayanan yang diberikan kepada pasien. Pelayanan tersebut meliputi waktu tunggu menjadi lama, fasilitas ruang tunggu yang kurang nyaman, persediaan obat-obatan serta fasilitas penunjang lainnya terkait Unit Kegiatan Perorangan (UKP).

Penyelenggaraan fungsi UKP pada Puskesmas dapat terlaksana dengan efektif dan efisien jika ada perencanaan yang matang baik dari segi tenaga kesehatan, pasien, maupun obatobatan. Salah satu hal yang penting sebelum melakukan perencanaan yaitu forecast atau forecasting. Forecast yang dapat dilakukan untuk mendapatkan perencanaan penyelenggaraan fungsi UKP pada Puskesmas adalah forecast jumlah pasien atau pengunjung Puskesmas Mulyorejo. Berdasarkan uraian di atas maka 
perlu dilakukan sebuah penelitian untuk mengetahui gambaran forecast jumlah kunjungan pasien di Puskesmas pada periode 2016 dengan menggunakan data kunjungan pasien pada periode Mei 2012-Desember 2015.

\section{METODE PENELITIAN}

Penelitian ini tergolong penelitian terapan, yaitu menerapkan metode statistik dalam hal ini metode forecast. Metode forecast yang digunakan adalah metode forecast exponensial smoothing. Lokasi penelitian dilakukan di Puskesmas Mulyorejo dengan mengambil data sekunder jumlah kunjungan pasien selama periode Mei 2012 sampai dengan Desember 2015. Waktu penelitian dilakukan selama 3 bulan yaitu pada bulan Februari-Maret 2015.

Pengambilan data dilakukan dengan cara mengambil 44 titik data historis yaitu jumlah kunjungan pasien periode Mei 2012 sampai dengan Desember 2015. Variabel dependent pada penelitian ini adalah jumlah kunjungan pasien sedangkan variabel independet adalah waktu dalam hal ini per bulan. Analisis data dilakukan dengan menghitung nilai MAPE (Mean Absolute Percentage Error). MAPE adalah nilai ratarata kesalahan hasil forecast yang digunakan untuk mengukur keakuratan metode forecast. Analisis data dilakukan dengan bantuan software komputer.

\section{HASIL}

\section{Karakteristik Pegawai di Puskesmas Mulyorejo}

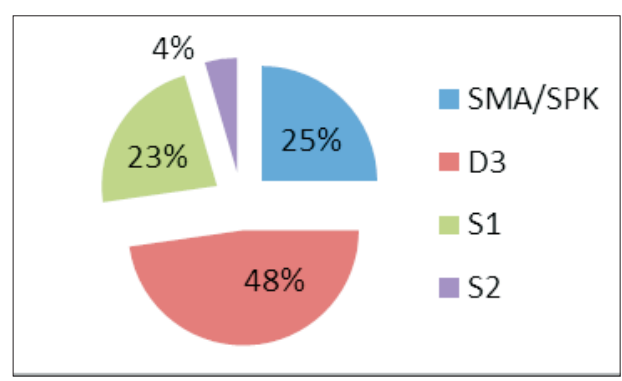

Gambar 1. Distribusi Jumlah Pegawai Menurut Latar Belakang Pendidikan di Puskesmas Mulyorejo.

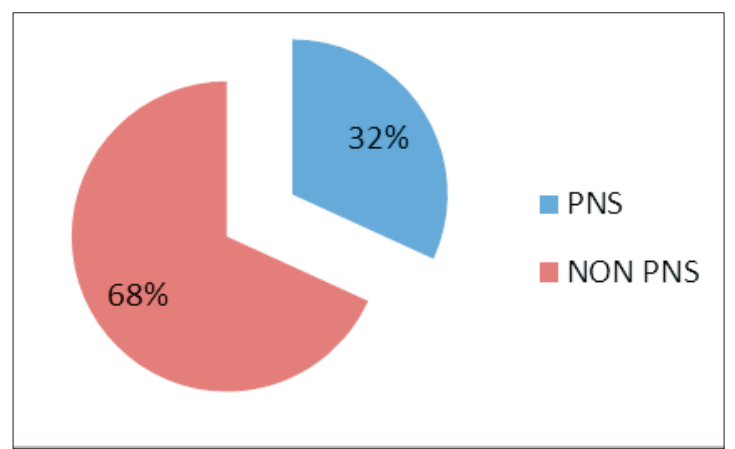

Gambar 2. Distribusi Jumlah Pegawai Menurut Status PNS/Non PNS di Puskesmas Mulyorejo.

Pegawai Puskesmas Mulyorejo didimonasi oleh lulusan D3 yaitu sebesar 48\% di mana ratarata dari mereka adalah akademi kebidanan dan keperawatan, sebanyak $25 \%$ pegawai puskesmas adalah lulusan SMA/SPK, 23\% lulusan S1, sedangkan yang paling sedikit adalah S2 yaitu sebesar $4 \%$.

Berdasarkan gambar 2 sumber daya yang ada di Puskesmas Mulyorejo sebagian besar berstatus non PNS yaitu sebesar $68 \%$. Sedangkan yang berstatus PNS sebesar 32\%.

\section{Karakteristik Kunjungan Pasien Puskesmas}

Gambar 3 menunjukkan grafik perbandingan jumlah kunjungan pasien dari tahun 2012-2015. Jumlah kunjungan pasien Puskesmas Mulyorejo mengalami fluktuasi tiap bulannya namun dari tahun ke tahun mengalami peningkatan. Jumlah kunjungan pasien tahun 2015 paling banyak dibandingkan tahun-tahun sebelumnya yakni tiap bulan mencapai2000-3500 pasien.

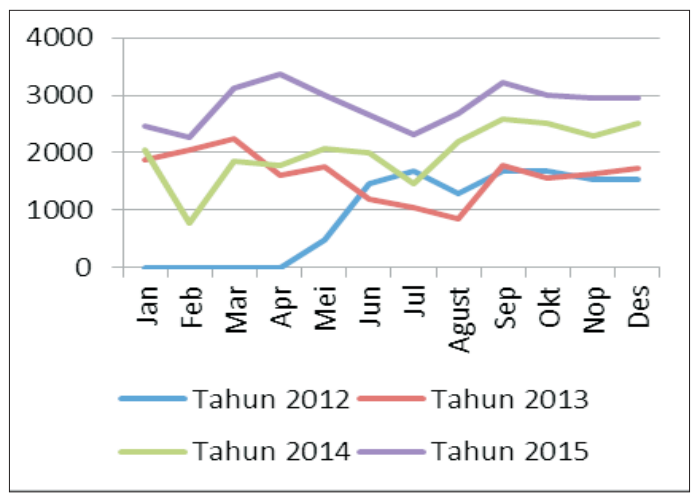

Gambar 3. Grafik Kunjungan Pasien Tahun 2012-2015. 


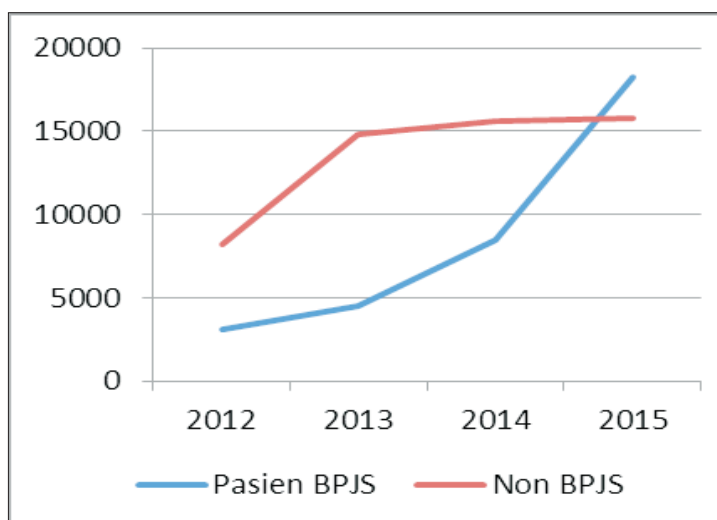

Gambar 4. Grafik Distribusi Kunjungan Pasien Berdasarkan Status BPJS dan Non BPJS.

Gambar 4 menunjukkan adanya peningkatan yang signifikan kunjungan pasien BPJS dari tahun 2014 ke tahun 2015. Secara keseluruhan jumlah pasien non BPJS lebih banyak dibandingkan pasien BPJS.

\section{Forecast Total Kunjungan Pasien Puskesmas Mulyorejo}

Hasil forecast menunjukkan total kunjungan tertinggi terletak pada bulan April tahun 2016 yaitu sebanyak 3367 orang. Penurunan terjadi terus menerus mulai dari bulan mei hingga jumlah pengunjung terendah terletak pada bulan Juli sebanyak 1735 orang, namun pada September jumlah kunjungan pasien naik lagi yaitu sebesar 3120 pasien.

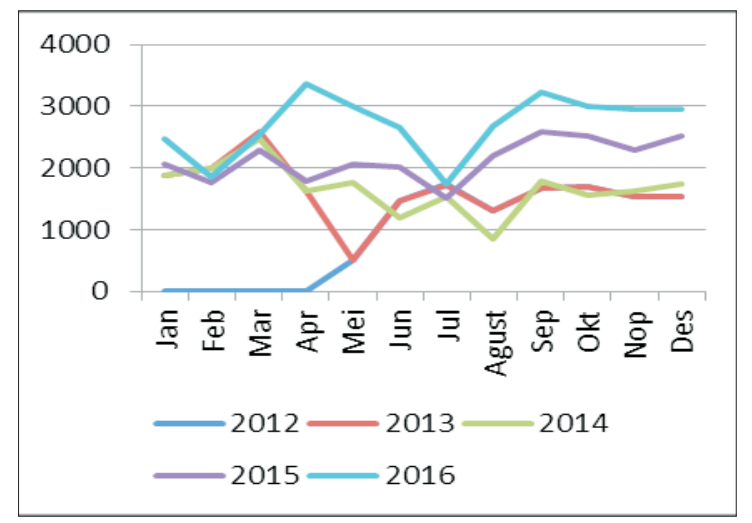

Gambar 5. Grafik Hasil Forecast Total Kunjungan Pasien Tahun 2012- 2016.

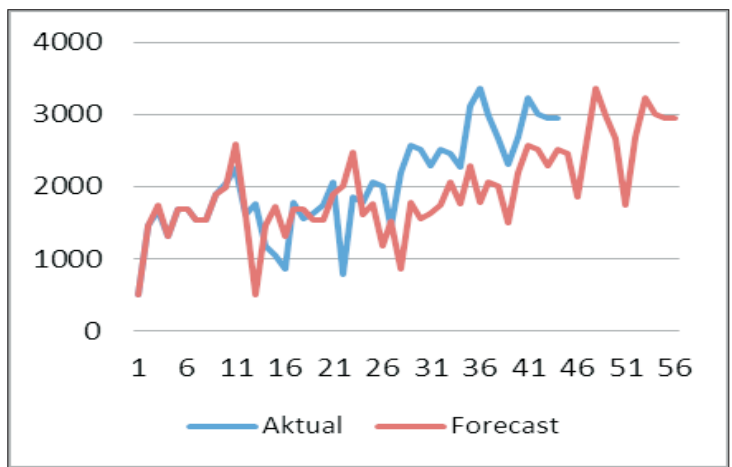

Gambar 6. Grafik Perbandingan Data Aktual dan Data Hasil Forecast Total Kunjungan Pasien.

Gambar 5 menunjukkan bahwa ada selisih yang besar antara data aktual dan data hasil forecast pada tahun 2013-2015. Selisih tersebut merupakan eror yang dihasilkan dari forecast tersebut.

Nilai MAPE yang dihasilkan pada forecast total kunjungan pasien berbeda-beda tiap bulannya. Nilai MAPE terkecil dihasilkan pada bulan Januari yaitu sebesar 8,742 , sedangkan terbesar dihasilkan pada forecast bulan Februari yaitu sebesar 59,808. Nilai MAPE tersebut dapat digunakan untuk mengetahui tingkat keakuratan hasil forecast. Hasil forecast total kunjungan pasien menunjukkan forecast pada bulan Januari lebih akurat dibanding bulan-bulan lainnya.

Tabel 1. Nilai MAPE (Mean Absolute Percentage Eror) Per Bulan

\begin{tabular}{lr}
\hline Bulan & MAPE \\
\hline Januari & 8,742 \\
Februari & 59,808 \\
Maret & 25,214 \\
April & 18,818 \\
Mei & 29,411 \\
Juni & 22,205 \\
Juli & 27,446 \\
Agustus & 33,105 \\
September & 14,161 \\
Oktober & 15,785 \\
Nopember & 14,235 \\
Desember & 14,408 \\
\hline
\end{tabular}




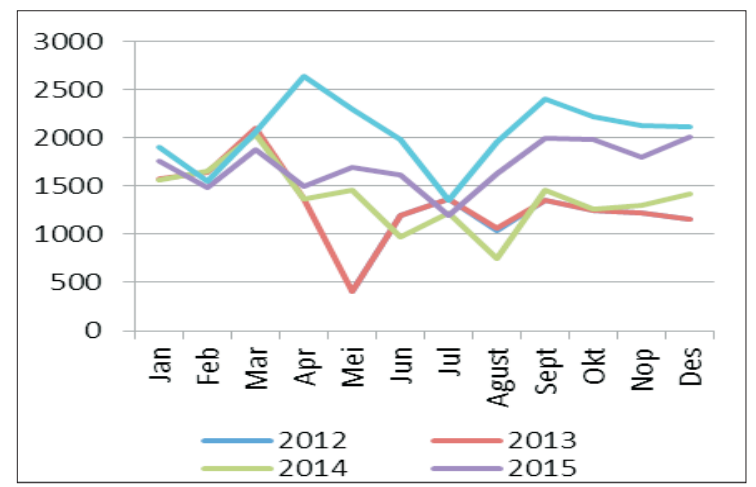

Gambar 7. Grafik Hasil Forecast Kunjungan Pasien Poli Umum Tahun 2012-2016.

\section{Forecast Kunjungan Pasien Poli Umum}

Hasil forecast menunjukkan jumlah kunjungan pasien poli umum tertinggi terletak pada bulan April tahun 2016 yaitu sebanyak 2643 orang. Penurunan terjadi terus menerus mulai dari bulan mei hingga jumlah pengunjung terendah terletak pada bulan Juli sebanyak 1347 orang.

Hasil forecast pada poli umum juga menunjukkan selisih yang besar antara data aktual dan data hasil forecast. Hasil forecast tahun 2016 menghasilkan kunjungan pasien poli umum yang fluktuasi.

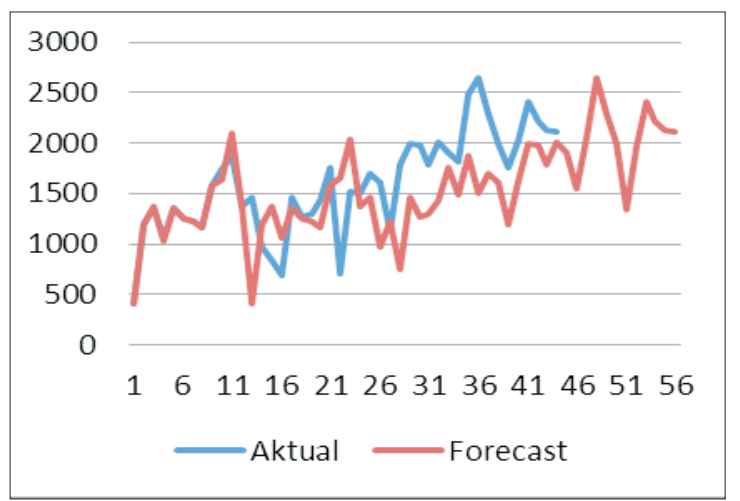

Gambar 8. Grafik Perbandingan Data Aktual dan Data Hasil Forecast Kunjungan Pasien Poli Umum.

Tabel 2 menunjukkan nilai MAPE atau tingkat kesalahan forecast jumlah kunjungan
Tabel 2. Nilai MAPE (Mean Absolute Percentage Eror) Per Bulan

\begin{tabular}{lc}
\hline Bulan & MAPE \\
\hline Januari & 6,069 \\
Februari & 53,817 \\
Maret & 23,381 \\
April & 17,35 \\
Mei & 28,013 \\
Juni & 20,345 \\
Juli & 26,226 \\
Agustus & 33,132 \\
September & 12,807 \\
Oktober & 11,956 \\
Nopember & 12,222 \\
Desember & 13,087 \\
\hline
\end{tabular}

pasien poli umum. Nilai MAPE terkecil dihasilkan pada forecast bulan Januari, sedangkan nilai MAPE terbesar dihasilkan pada forecast bulan Februari.

\section{Forecast Kunjungan Pasien Poli Gigi}

Hasil forecast menunjukkan jumlah kunjungan pasien poli gigi tertinggi terletak pada bulan Oktober dan Desember tahun 2016 yaitu sebanyak 322 orang, sedangkan jumlah pengunjung terendah terletak pada bulan Februari sebanyak 154 orang.

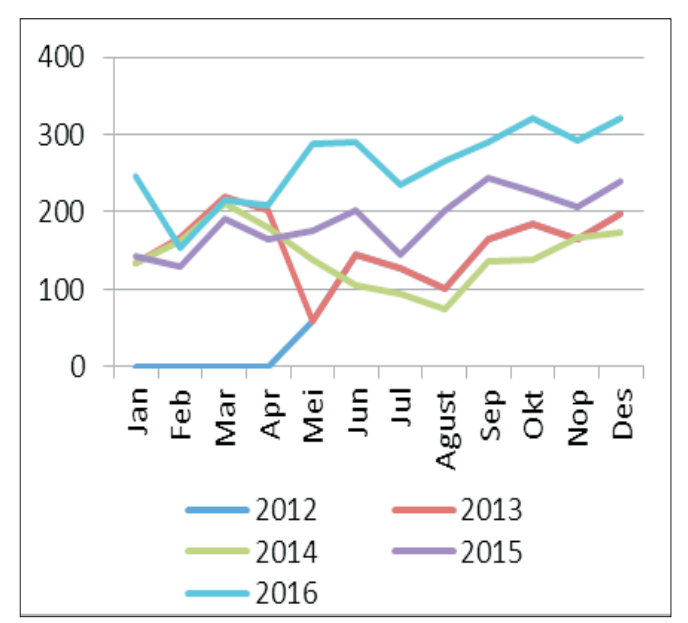

Gambar 9. Grafik Hasil Forecast Kunjungan Pasien Poli Gigi Tahun 2012-2016. 


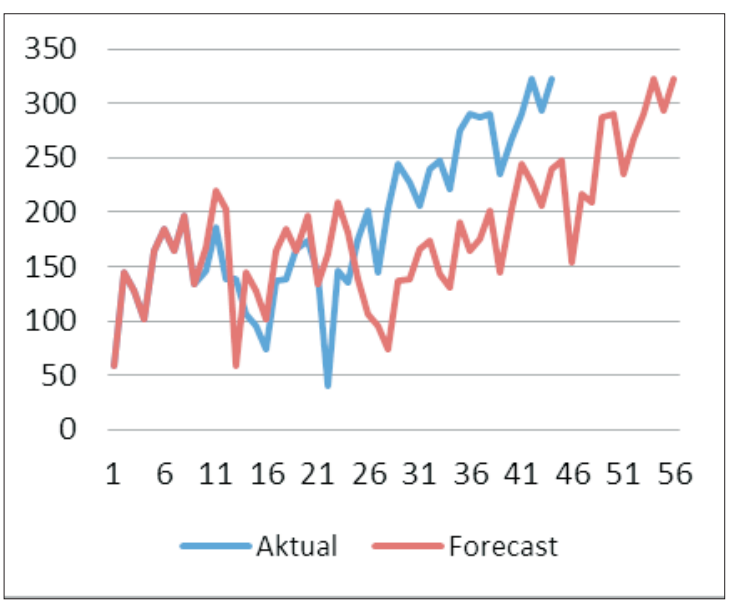

Gambar 10. Grafik Perbandingan Data Aktual dan Data Hasil Forecast Kunjungan Pasien Poli Gigi.

Hasil forecast jumlah kunjungan pasien mengalami fluktuasi tiap bulannya. Selisih yang dihasilkan antara data aktual dan data hasil forecast juga sangat besar. Hal ini menyebakan tingkat kesalahan forecast juga besar, sehingga tingkat keakuratan forecast juga kecil.

Tabel 3 menunjukkan nilai MAPE atau tingkat kesalahan forecast yang dihasilkan pada forecast kunjungan pasien poli gigi. Nilai MAPE terkecil dihasilkan pada forecast bulan November yaitu sebesar 12,579 sedangkan nilai MAPE terbesar dihasilkan pada bulan Februari yaitu sebesar 120,188.

Tabel 3. Nilai MAPE (Mean Absolute Percentage Eror) Per Bulan

\begin{tabular}{lc}
\hline \multicolumn{1}{c}{ Bulan } & MAPE \\
\hline Januari & 16,133 \\
Februari & 120,188 \\
Maret & 30,973 \\
April & 40,0599 \\
Mei & 29,379 \\
Juni & 28,726 \\
Juli & 26,879 \\
Agustus & 31,001 \\
September & 19,899 \\
Oktober & 25,692 \\
Nopember & 12,579 \\
Desember & 16,546 \\
\hline
\end{tabular}

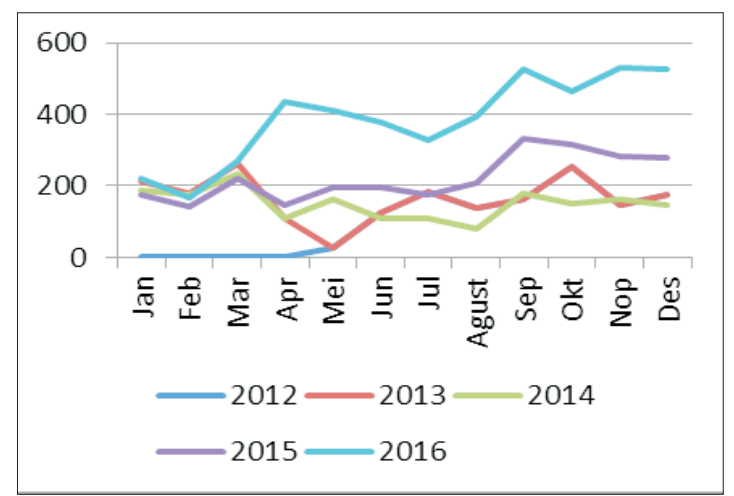

Gambar 11. Grafik Hasil Forecast Jumlah Kunjungan Pasien Poli KIA Tahun 2012-2016.

\section{Forecast Kunjungan Pasien Poli KIA}

Hasil forecast menunjukkan jumlah kunjungan pasien Poli KIA tertinggi terletak pada bulan November tahun 2016 yaitu sebanyak 529 orang, sedangkan jumlah pengunjung terendah terletak pada bulan Februari tahun 2016 sebanyak 167 orang.

Hasil forecast jumlah kunjungan pasien poli KIA menghasilkan selisih yang besar dengan data aktual. Selisih tersebut dapat mempengaruhi tingkat kesalahan forecast. Sehingga tingkat keakuratan forecast juga semakin besar. Jumlah kunjungan pasien poli KIA terus mengalami kenaikan pada bulan-bulan akhir.

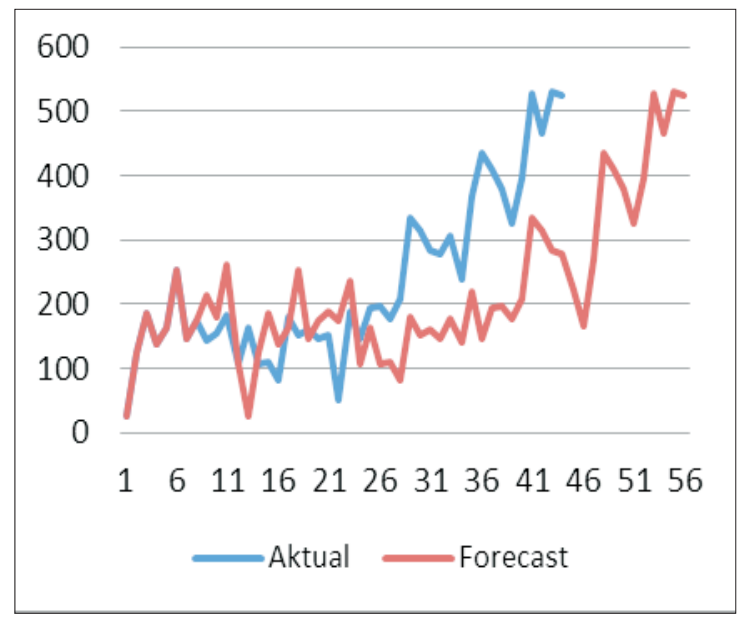

Gambar 12. Grafik Perbandingan Data Aktual dan Data Hasil Forecast Kunjungan Pasien Poli KIA. 
Tabel 4. Nilai MAPE (Mean Absolute Percentage Eror) Per Bulan

\begin{tabular}{lr}
\hline \multicolumn{1}{c}{ Bulan } & MAPE \\
\hline Januari & 37,978 \\
Februari & 101,708 \\
Maret & 35,739 \\
April & 30.796 \\
Mei & 38,048 \\
Juni & 27,398 \\
Juli & 37,977 \\
Agustus & 43,748 \\
September & 23,239 \\
Oktober & 38,149 \\
Nopember & 24,89 \\
Desember & 28,624 \\
\hline
\end{tabular}

Nilai MAPE yang dihasilkan dari forecast kunjungan pasien poli KIA rata-rata $30-40 \%$. Nilai MAPE terkecil dihasilkan pada forecast kunjungan pasien poli KIA bulan September yaitu sebesar 23,139 sedangkan nilai MAPE terkecil dihasilkan pada forecast bulan Februari yaitu sebesar 101,708.

\section{PEMBAHASAN}

Data total kunjungan pasien Puskesmas Mulyorejo berpola fluktuasi tanpa ada unsur tren maupun musiman. Pola data seperti data tersebut sangat sesuai untuk dilakukan forecast menggunakan single exponensial smoothing. Menurut Kristyanto metode single exponensial smoothing sesuai untuk meramalakan data yang jenis pola datanya fluktuasi acak, tanpa ada unsur tren dan musiman (Krityanto, 2012).

Metode single exponensial smoothing merupakan metode forecast dengan cara penghalusan fluktuasi dari hasil forecast. Forecast dengan metode single exponensial smoothing pada setiap datanya akan diberikan bobot yang disimbolkan dengan alpha. Nilai alpha berkisar antar 0 sampai dengan 1 (Biri dkk, 2013). Nilai alpha pada model forecast yang digunakan untuk total kunjungan pasien ditentukan dari hasil trial and eror. Nilai alpha yang didapat setelah proses trial and eror adalah 0,05. Nilai alpha sebesar 0,05 ini kemudian dimasukkan ke dalam model forecast single exponensial smoothing dengan pengolahan dengan bantuan software komputer.
Ukuran keakuratan metode forecast dapat dilihat dengan beberapa parameter yaitu MAD, MSE, dan MAPE. MAD (Mean Absolute Deviation) adalah rata-rata kesalahan absolut dari hasil forecast. MSE (Mean Square Error) adalah rata-rata kuadrat eror hasil forecast. MAPE (Mean Absolute Percentage Eror) adalah nilai yang dihasilkan dari menghitung rata-rata persentase kesalahan. Perhitungan nilai MAPE digunakan untuk mengetahui tingkat keakuratan forecast (Sahli, 2013). Penggunaan nilai alpha sebesar 0,05 pada model forecast ini menghasilkan MAPE yang berbeda-beda setiap bulannya. Nilai MAPE yang berbeda-beda setiap bulannya ini dihasilkan karena forecast dilakukan tiap bulan dengan menggunakan data tahunan. Nilai MAPE yang terkecil untuk forecast total kunjungan pasien Puskesmas Mulyorejo adalah pada bulan Januari yaitu 8,742. Nilai MAPE ini menunjukkan bahwa forecast pada bulan Januari lebih akurat dibandingkan bulan-bulan lainnya.

Dari hasil forecast dapat diketahui bahwa kenaikan jumlah kunjungan pasien terjadi pada bulan-bulan memasuki musim pancaroba. Pada tahun 2016 kenaikan jumlah kunjungan pasien terjadi pada bulan April sebesar 3367 pasien yaitu naik $32,4 \%$ dari bulan sebelumnya. Jumlah kunjungan pasien terendah pada bulan Juli sebesar 1735 pasien yaitu turun 34,6\% dari bulan sebelumnya. Kenaikan tersebut terjadi karena pada bulan April telah memasuki musim pancaroba. Penurunan jumlah kunjungan pasien terjadi pada bulan-bulan Ramadhan dan Idul Fitri, di mana pada bulan-bulan tersebut jam buka pelayanan setiap harinya pada bulan tersebut tidak penuh. Penurunan juga dapat terjadi karena banyak masyarakat di wilayah kerja Puskesmas Mulyorejo pulang ke kampung halaman.

Data kunjungan pasien poli umum Puskesmas Mulyorejo berpola fluktuasi tanpa ada unsur tren maupun musiman. Pola data seperti data tersebut sangat cocok untuk dilakukan forecast menggunakan single exponensial smoothing. Metode single exponensial smoothing merupakan metode forecast dengan cara penghalusan fluktuasi dari hasil forecast. Forecast dengan metode single exponensial smoothing pada setiap datanya akan diberikan bobot yang disimbolkan dengan alpha. Nilai alpha berkisar antar 0 sampai dengan 1 . 
Nilai alpha pada model forecast yang digunakan untuk total kunjungan pasien ditentukan dari hasil trial and eror. Nilai alpha yang didapat setelah proses trial and eror adalah 0,05 . Nilai alpha sebesar 0,05 ini kemudian dimasukkan ke dalam model forecast single exponensial smoothing dengan bantuan komputer.

MAPE (Mean Absolute Percentage Eror) adalah nilai yang dihasilkan dari menghitung rata-rata persentase kesalahan. Perhitungan nilai MAPE digunakan untuk mengetahui tingkat keakuratan forecast. Penggunaan nilai alpha sebesar 0,05 pada model forecast ini menghasilkan MAPE yang berbeda-beda setiap bulannya. Nilai MAPE yang berbeda-beda setiap bulannya ini dihasilkan karena forecast dilakukan tiap bulan dengan menggunakan data tahunan. Nilai MAPE yang terkecil untuk forecast total kunjungan pasien Puskesmas Mulyorejo adalah pada bulan Januari yaitu 6,069. Nilai MAPE ini menunjukkan bahwa forecast pada bulan januari lebih akurat dibandingkan bulan-bulan lainnya.

Dari hasil forecast dapat diketahui bahwa kenaikan jumlah kunjungan pasien poli umum terjadi pada bulan-bulan memasuki musim pancaroba. Pada tahun 2016 kenaikan jumlah kunjungan pasien terjadi pada bulan April sebesar 2643 pasien yaitu $22,1 \%$ dari bulan sebelumnya. Jumlah kunjungan pasien terendah pada bulan Juli sebesar 1347 pasien yaitu turun 32,1\% dari bulan sebelumnya.

Kenaikan tersebut terjadi karena pada bulan April telah memasuki musim pancaroba, di mana pada musim pancaroba muncul penyakit-penyakit yang menyertai musim tersebut. Penyakitpenyakit tersebut diantaranya adalah batuk dan pilek yang banyak diderita masyarakat khususnya Mulyorejo saat musim pancaroba.

Penurunan jumlah kunjungan pasien terjadi pada bulan-bulan Ramadhan dan Idul Fitri, di mana pada bulan-bulan tersebut jam buka pelayanan setiap harinya pada bulan tersebut tidak penuh. Penurunan juga dapat terjadi karena banyak masyarakat di wilayah kerja Puskesmas Mulyorejo pulang ke kampung halaman.

Jumlah kunjungan pasien poli umum merupakan penyumbang jumlah kunjungan pasien terbanyak daripada poli-poli lainnya. Sebagian besar pasien Puskesmas Mulyorejo merupakan pasien yang berobat di poli umum. Selain berobat poli umum juga melayani permintaan surat keterangan sehat ataupun sakit sehingga banyak pasien yang memanfaatkan pelayanan di poli umum meskipun mereka sebenarnya tidak sakit.

Data kunjungan pasien poli gigi Puskesmas Mulyorejo berpola fluktuasi tanpa ada unsur tren maupun musiman. Pola data seperti data tersebut sangat cocok untuk dilakukan forecast menggunakan single exponensial smoothing. Metode single exponensial smoothing merupakan metode forecast dengan cara penghalusan fluktuasi dari hasil forecast. Forecast dengan metode single exponensial smoothing pada setiap datanya akan diberikan bobot yang disimbolkan dengan alpha. Nilai alpha berkisar antar 0 sampai dengan 1 .

Nilai alpha pada model forecast yang digunakan untuk total kunjungan pasien ditentukan dari hasil trial and eror. Nilai alpha yang didapat setelah proses trial and eror adalah 0,05 . Nilai alpha sebesar 0,05 ini kemudian dimasukkan ke dalam model forecast single exponensial smoothing dengan pengolahan dengan bantuan software komputer.

MAPE (Mean Absolute Percentage Eror) adalah nilai yang dihasilkan dari menghitung rata-rata persentase kesalahan. Perhitungan nilai MAPE digunakan untuk mengetahui tingkat keakuratan forecast. Penggunaan nilai alpha sebesar 0,05 pada model forecast ini menghasilkan MAPE yang berbeda-beda setiap bulannya. Nilai MAPE yang berbeda-beda setiap bulannya ini dihasilkan karena forecast dilakukan tiap bulan dengan menggunakan data tahunan. Nilai MAPE yang terkecil untuk forecast total kunjungan pasien Puskesmas Mulyorejo adalah pada bulan November yaitu 12,579. Nilai MAPE ini menunjukkan bahwa forecast pada bulan November lebih akurat dibandingkan bulan-bulan lainnya.

Hasil forecast jumlah pengunjung Poli Gigi di Puskesmas Mulyorejo tahun 2016 mengalami fluktuasi tiap bulannya, namun fluktuasi tersebut cenderung meningkat pada bulan September, Oktober, November, dan Desember. Peningkatan tersebut disebabkan karena pada bulan September ada program Bulan Kesehatan Gigi Nasional di mana ada sebuah reward untuk pasien yang 
memeriksakan giginya sehingga memotivasi masyarakat untuk datang ke Poli Gigi Puskesmas Mulyorejo.

Peningkatan jumlah pasien tersebut juga dikarenakan ada program skrining berkala untuk anak SD khususnya pemeriksaan gigi. Jumlah kunjungan pasien poli gigi paling banyak pada bulan Oktober dan Desember sebesar 322 pasien yaitu $10,6 \%$ dari bulan sebelumnya. Jumlah kunjungan terendah pada bulan Februari sebesar 154 pasien yaitu turun $37,6 \%$ dari bulan sebelumnya.

Data kunjungan pasien poli KIA Puskesmas Mulyorejo berpola fluktuasi tanpa ada unsur tren maupun musiman. Pola data seperti data tersebut sangat cocok untuk dilakukan forecast menggunakan single exponensial smoothing. Metode single exponensial smoothing merupakan metode forecast dengan cara penghalusan fluktuasi dari hasil forecast. Forecast dengan metode single exponensial smoothing pada setiap datanya akan diberikan bobot yang disimbolkan dengan alpha. Nilai alpha berkisar antar 0 sampai dengan 1.

Nilai alpha pada model forecast yang digunakan untuk total kunjungan pasien ditentukan dari hasil trial and eror. Nilai alpha yang didapat setelah proses trial and eror adalah 0,05 . Nilai alpha sebesar 0,05 ini kemudian dimasukkan ke dalam model forecast single exponensial smoothing dengan pengolahan dengan bantuan software komputer.

MAPE (Mean Absolute Percentage Eror) adalah nilai yang dihasilkan dari menghitung rata-rata persentase kesalahan. Perhitungan nilai MAPE digunakan untuk mengetahui tingkat keakuratan forecast. Penggunaan nilai alpha sebesar 0,05 pada model forecast ini menghasilkan MAPE yang berbeda-beda setiap bulan. Nilai MAPE yang berbeda-beda setiap bulan ini dihasilkan karena forecast dilakukan tiap bulan dengan menggunakan data tahunan.

Nilai MAPE yang terkecil untuk forecast total kunjungan pasien Puskesmas Mulyorejo adalah pada bulan September yaitu 23,139. Nilai MAPE ini menunjukkan bahwa forecast pada bulan September lebih akurat dibandingkan bulan-bulan lainnya.
Dari hasil forecast dapat diketahui bahwa kenaikan jumlah kunjungan pasien terjadi pada bulan November sebanyak 529 pasien yaitu $13,7 \%$ dari bulan sebelumnya. Jumlah kunjungan pasien paling sedikit terjadi pada bulan Februari sebesar 168 orang yaitu turun $24,5 \%$ dari bulan sebelumnya. Kenaikan ini disebabkan karena banyak masyarakat khususnya para istri yang berKB dan imunisasi pada bayi di bulan tersebut. Selain itu poli KIA juga melayani imunisasi TT untuk perempuan yang akan menikah, sehingga kemungkinan pada bulan yang diperkirakan akan mengalami kenaikan jumlah kunjungan pasien tersebut dapat terjadi karena adanya musim menikah. Peningkatan juga dapat dipengaruhi oleh adanya PIN dimana akan ada reward yang diberikan pada peserta imunisasi yang datang ke poli KIA untuk imunisasi.

\section{SIMPULAN DAN SARAN}

\section{Simpulan}

Hasil forecast jumlah kunjungan pasien di Puskesmas Mulyorejo tahun 2016 secara umum mengalami fluktuasi tiap bulannya. jumlah kunjungan terbesar terjadi pada bulan April sedangkan jumlah kunjungan terkecil terjadi pada bulan Juli. Jumlah kunjungan pasien poli umum terbesar terjadi pada bulan April sedangkan jumlah terendah terjadi pada bulan Juli.

Jumlah kunjungan pasien poli gigi terbesar pada bulan Oktober dan Desember sedangkan terkecil terjadi pada bulan Februari. Jumlah kunjungan pasien poli KIA paling banyak terjadi pada bulan November sedangkan paling sedikit terjadi pada bulan Februari. Nilai MAPE terkecil untuk forecast total kunjungan pasien Puskesmas Mulyorejo adalah 8,742 yaitu pada bulan Januari.

Nilai MAPE terkecil untuk forecast jumlah kunjungan poli umum adalah 6.609 yaitu pada bulan Januari. Nilai MAPE terkecil untuk forecast jumlah kunjungan poli gigi adalah 12,579 yaitu pada bulan November. Nilai MAPE terkecil untuk forecast jumlah kunjungan pasien poli KIA adalah 23,239 yaitu pada bulan November. Peningkatan dan penurunan jumlah kunjungan 
pasien di Puskesmas Mulyorejo dominan dipengaruhi oleh jumlah kunjungan pasien di Poli Umum karena di poli umum memberikan banyak pelayanan selain pelayanan berobat.

Peningkatan jumlah kunjungan pasien di poli umum paling tinggi terjadi pada bulan-bulan musim pancaroba, sedangkan penurunan jumlah kunjungan pasien terjadi pada bulan Ramadhan dan Idul Fitri. Peningkatan jumlah kunjungan pasien paling tinggi di Poli Gigi terjadi pada bulan dimana ada program Bulan Kesehatan Gigi Nasional. Peningkatan jumlah kunjungan pasien Poli KIA terjadi secara tidak menentu. Peningkatan tersebut dapat dipengaruhi adanya pekan imunisasi.

\section{Saran}

Saran yang diharapkan bagi pengambil kebijakan dari kesimpulan diatas adalah sebaiknya dilakukan perencanaan terkait alat, obat, serta tenaga kesehatan yang dibutuhkan pada bulan di mana diramalkan jumlah kunjungan akan mengalami peningkatan di masing-masing Poli yang ada di Puskesmas Mulyorejo.

Perencanaan yang dapat dilakukan salah satunya dengan menambah sumber daya yang ada dibagian loket, loket merupakan pelayanan yang paling awal yang diterima oleh pasien. Ruang tunggu untuk pasien mengantri perlu ditambah fasilitas kursi, karena pada hari-hari tertentu kunjungan pasien melebihi kapasitas ruang tunggu yang tersedia dan sebagian ada yang tidak mendapat tempat duduk untuk menunggu.

Pada poli umum perlu dilakukan perencanaan terkait jumlah perawat serta dokter yang melayani pasien. Selain itu ruang pelayanan untuk poli umum juga terlalu sempit sehingga apabila ditambah tenaga kesehatan lagi ruangnya kurang memadai. Jumlah kunjungan pasien yang mengalami penurunan hendaknya dilakukan evaluasi terkait penurunan jumlah kunjungan di masing-masing poli tersebut.

Forecast akan lebih efektif jika eror atau kesalahan yang dihasilkan kecil. Perlu penelitian lebih lanjut tentang metode forecast yang tepat untuk forecast jumlah kunjungan pasien. Setiap metode forecast dipengaruhi oleh jumlah data yang digunakan serta pola data yang digunakan. Jumlah titik data yang lebih banyak akan menghasilkan forecast yang lebih baik pula. Pemilihan metode forecast sebaiknya memperhatikan bentuk pola datanya.

\section{DAFTAR PUSTAKA}

Biri, R., Langi, Y.A.R., Paendong, M.S. 2013. Penggunaan Metode Exponensial Smoothing dalam Meramal Pergerakan Inflasi Kota Palu. Jurnal Ilmiah Sains. Vol. 13.

Farihul, M.L., Anggraeni, W., Aulia, V.R. 2012. Prediksi Jumlah Kunjungan Pasien Rawat Jalan Menggunakan Metode Genetic Fuzzy Systems: Studi Kasus Rumah Sakit Usada Sidoarjo. Jurnal Teknik ITS. Vol. 1.

Fuad., Wahyuni. 2014. Prediksi Kunjungan Pasien Baru Perbangsal Rawat Inap Tahun 2015 dengan Metode ARIMA di BLUD RSU Banjar. Jurnal Manajemen Informasi Kesehatan Indonesia. Vol. 3.

Gaspersz. 2005. Production Planning and Inventory Control, Gramedia Pustaka Utama: Jakarta.

Hartono, dkk. 2012. Perbandingan Metode Single Exponensial Smoothing dan Metode Exponensial Smoothing Adjusted for Trend (Holt's Method) untuk Meramalkan Penjualan (Studi Kasus: Toko Onderdil Mobil "Prodi Purwodadi"). Jurnal Eksis. Vol. 5.

Kristyanto, W.A. 2012. Prediksi Periode Serangan Demam Berdarah Dengue (DBD) Berdasarkan Dasarian Awal Bulan Hujan Menggunakan Metode Exponential Smoothing. Salatiga. Program Studi Teknik Informatika FTIUKSW.

Raharja,dkk. 2010. Penerapan Metode Exponensial Smoothing untuk Forecast Penggunaan Waktu Telepon di PT. Telkomsel Divre3 Surabaya. Jurnal Sistem Informasi.

Sahli, M., 2013. Penerapan Metode Exponensial Smoothing dalam Sistem Informasi Pengendalian Persediaan Bahan Baku (Studi Kasus Toko Tirta Harum). Jurnal Simetris. Vol. 3.

Sudian, T. 2010. Hubungan Pelayanan Pasien Terhadap Mutu Pelayanan Kesehatan RS Cut Mutia Kabupaten Aceh Utara. Jurnal Kesehatan Masyarakat. 
Tannady, H., Andrew, F. 2013. Analisis Perbandingan Metode Regresi Linier dan Exponensial Smoothing dalam Parameter Tingkat Error. Jurnal Teknik dan Ilmu Komputer. Vol.

Wardhani, A.R., Pereira, S.M. 2010. Studi Analisis Forecast.
Forecast dengan Metode Deret Berkala. Widya Teknika. Vol. 18.

Yuniastari, K., Wirawan, IGP. 2014. "Permintaan Produk Perak Menggunakan Metode Moving Average dan Exponensial Smoothing". Jurnal Sistem Informatika. 